University of Wollongong

Research Online

Faculty of Engineering - Papers (Archive)

Faculty of Engineering and Information

Sciences

$1-1-2008$

\title{
Finite element simulation of mandrel penetration in a normally consolidated soil
}

Cholachat Rujikiatkamjorn

University of Wollongong, cholacha@uow.edu.au

Ali Ghandeharioon

University of Wollongong, ag781@uow.edu.au

Buddhima Indraratna

University of Wollongong, indra@uow.edu.au

Follow this and additional works at: https://ro.uow.edu.au/engpapers

Part of the Engineering Commons

https://ro.uow.edu.au/engpapers/838

\section{Recommended Citation}

Rujikiatkamjorn, Cholachat; Ghandeharioon, Ali; and Indraratna, Buddhima: Finite element simulation of mandrel penetration in a normally consolidated soil 2008, 287-292.

https://ro.uow.edu.au/engpapers/838

Research Online is the open access institutional repository for the University of Wollongong. For further information contact the UOW Library: research-pubs@uow.edu.au 


\title{
Finite element simulation of mandrel penetration in a normally consolidated soil
}

\author{
C. Rujukiatkamjorn, A. Ghandeharioon \& B. Indraratna \\ School of Cill. Mining and Environmental Engineering, University of Wollongong, Wollongong, Australia
}

\begin{abstract}
In this paper; a finite element simulation of the mandrel penetration in normally consolidated soils is presented using a commercial finite element code (ABAQUS). A coupled analysis with large-strain frictional contact is used to simulate the soil-mandrel interface during mandrel penetration. The modified Cam clay model is used to represent the soft soil. The numerical predictions are then compared with the results obtained from the large scale laboratory tests to predict the extent of the smear zone. A large scale consolidation test was conducted with the rate-controlled device used to install the mandrel. The associated excess pore pressures at various locations were recorded and compared with the numerical predications.
\end{abstract}

\section{INTRODUCTION}

The application of preloading with prefabricated ver tical drains (PVDs) is regarded as one of the classic and popular methods in soil improvement practices. However the installation of vertical drains using a steel mandrel significantly alters the subsoil properties and causes pore water pressure to build up during installation of the mandrel, especially in its immediate vicinity (Sathananthan and Indraratna, 2006; Sharma and Xiao, 2000). The resulting smear zone will cause a reduction in lateral permeability which adversely affects consolidation (Indraratna and Redana, 2000).

In many classical theories (Barron, 1948; Hansbo, 1981), the influence of mandrel driving is analysed with an idealised two-zone model, i.e., an undisturbed zone with natural permeability and a smear zone with reduced permeability. The accuracy of the predictions using the aforementioned theories depends on a correct assessment of the extent of the smear zone and horizontal permeability.

Both the diameter and permeability of the smear zone are often difficult to quantify from laboratory tests. For example Indraratna and Redana (1998) Sharma and Xiao (2000) and Sathananthan and Indraratna (2006) conducted laboratory tests to evaluate the smear zone parameters using specially designed large scale consolidation test apparatus. Sharma and Xiao (2000) proposed that the radius of the smear zone is about four times the radius of the mandrel and the horizontal permeability of the clay in the smear zone is approximately 1.3 times smaller than that in the outer (undisturbed) zone. Walker and
Indraratna (2006) proposed that the estimated smear zone could be 4.5 times larger than the equivalent radius of the drain and that the horizontal to vertical permeability ratio $\left(k_{l} / k_{v}\right)$ is close to unity in the smear zone. So far there is no comprehensive or standard method for predicting the area of the smear zone. Due to advancements in finite element codes the numerical simulation of a large strain condition may be used to capture the characteristics of load deformation during installation of the mandrel. This method is usually used to analyse installation of the pile (Sheng et al. 2005; Walker and Yu, 2006). The advantages are the availability of a complete picture of the stress-strain relationships and the mandrel-soil interaction.

According to Small et al. (1976), the behaviour of saturated clays under rapid loading occurs under fully undrained conditions and therefore the study of mandrel penetration in saturated clay is essentially an undrained analysis. During installation, the excess pore pressure can be induced as the result of the change in the octahedral normal stress $\left(\Delta \sigma_{\text {oct }}\right)$ and the octahedral shear stress $\left(\Delta \tau_{\text {oc }}\right)$ (Burns and Maynes, 1998). While the volumetric strain remains constant during undrained conditions, and so does the octahedral normal stress, variations in the shear strain adjacent to the side of the mandrel alters the octahedral shear stress. This zone of disturbance depends on the size and shape of the mandrel, soil properties, installation speed, and geometry of the cone (Kim et al. 2007)

A numerical analysis based on large strain frictional contact is used in this paper to simulate mandrel 
penetration. A large strain frictional contact based on the Lagrangian multiplier method is used to model the interaction between soil and mandrel. This coupled analysis is also used to simulate the excess pore pressure generated during installation of the mandrel. The numerical results are then compared with the large scale laboratory results.

\section{LARGE SCALE TESTS}

An $0.65 \mathrm{~m}$ internal diameter $\times 1.04 \mathrm{~m}$ high $\times 0.008 \mathrm{~m}$ thick radial drainage consolidometer (Fig, 1) with a $1.4 \mathrm{~mm}$ thick very smooth Teflon sleeve fitted around the internal cell boundary to minimise friction, was used. The surcharge loading can be applied on the top by an air jack compressor piston. Several strain gauge type pore pressure transducers (T1-T5) with distances from the centre of $125,135,155,185$ and $250 \mathrm{~mm}$, respectively, are installed radially (Fig. 2), at a depth of $0.5 \mathrm{~m}$ from the bottom to monitor the pore pressure while the mandrel is installed.

The main steps involved in this test are preparation of a clay sample, installation of the prefabricated vertical drain, and collection of samples at the end of consolidation to measure the permeability and water content. These procedures are mentioned elsewhere by Indraratna and Redana (1998). An initial

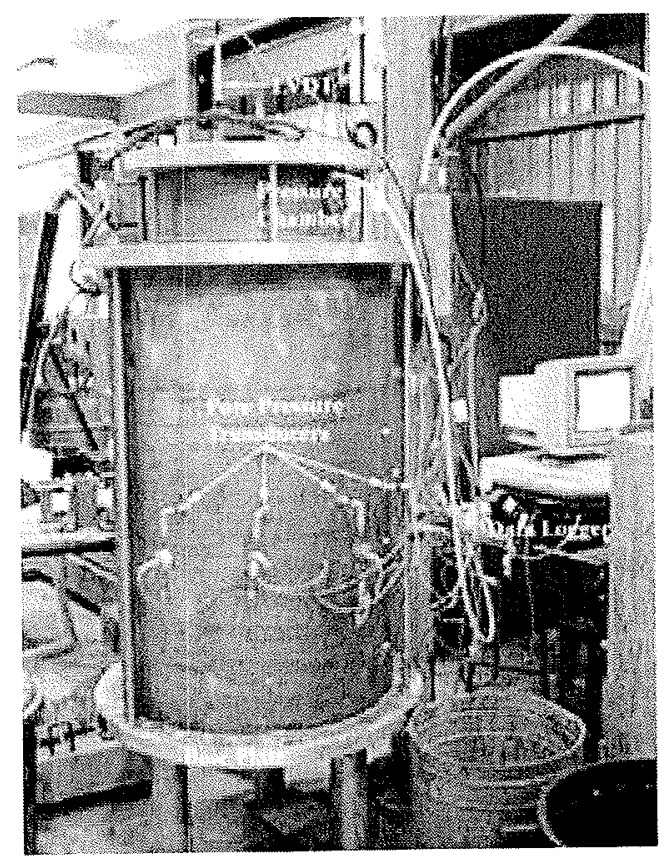

Figure 1. Large-scale radial drainage consolidometer (Sathananthan and Indraratna, 2006).

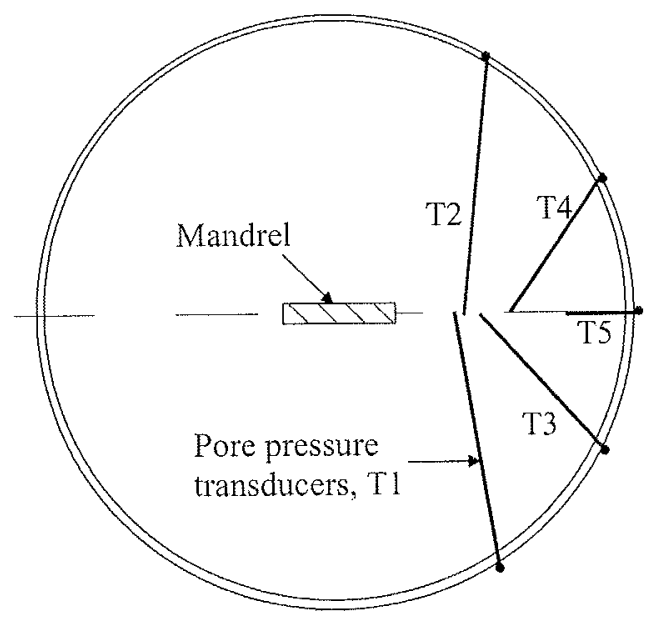

Figure 2. Location of pore pressure transducers (Sathananthan, 2006).

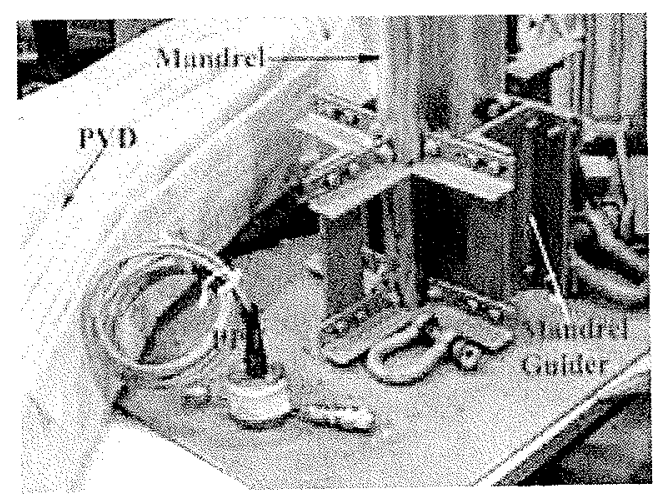

Figure 3. Mandrel, Guider and Pore pressure transducer assembly (Sathananthan and Indraratna, 2006).

pre-consolidation pressure of $20 \mathrm{kPa}$ was applied prior to installing the drain.

A single prefabricated vertical band drain $(100 \mathrm{~mm} \times 3 \mathrm{~mm})$ was installed at a rate of $0.5 \mathrm{~m} / \mathrm{min}$ using a specially designed $125 \mathrm{~mm} \times 25 \mathrm{~mm}$ rectangular mandrel (Fig. 3). The radius of the mandrel $\left(r_{\mathrm{m}}\right)$, is $31.5 \mathrm{~mm}$, based on the equivalent area. The end of the drain was attached to a 'shoe' to anchor it at the predetermined depth $(0.95 \mathrm{~m}$ from the surface) when the mandrel was withdrawn.

\section{FINITE ELEMENT MODEL}

The geometry and boundary conditions of the finite element analysis for mandrel penetration are shown 
in Fig. 4. Axisymmetric 4-node bilinear displacement and pore pressure elements (CAX4P) and axisymmetric 4-node bilinear displacement elements (CAX4) are used respectively for the soil and mandrel. An elastic model and a modified Cam-clay model are respectively used for the mandrel and soil and their properties are summarised in Table 1.

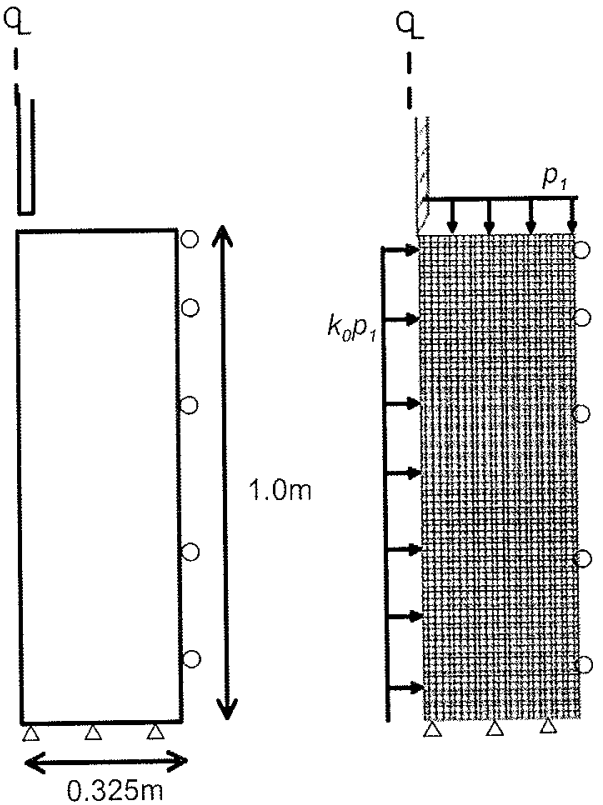

Figure 4. Geometry, Mesh and boundary conditions for a large-scale test.

Table 1. Soil and steel mandrel properties used in the finite element analysis.

\begin{tabular}{ll}
\hline Soil Properties & Value \\
\hline Slope of unloading-reloading line, $\kappa$ & 0.05 \\
Slope of normal compression line, $\lambda$ & 0.15 \\
Critical state line slope, $\mathrm{M}$ & 1.1 \\
Critical state void ratio, $\mathrm{e}_{t s}$ & 1.55 \\
Poisson's ratio, $v($ assumed) & 0.25 \\
Permeability $(\mathrm{m} / \mathrm{s})$ & $5.1 \times 10^{-10}$ \\
Lateral stress coefficient $\left(k_{b}\right)$ & 0.5 \\
Steel Mandrel Properties & Value \\
Young modulus $\left(\mathrm{kN} / \mathrm{m}^{2}\right)$ & $2 \times 10^{8}$ \\
Poisson's ratio, $v$ & 0.25 \\
Interface Propertics & Value \\
Friction coefficient, $\mu$ & 0.24 \\
\hline
\end{tabular}

A circular mandrel of equivalent area is used in this analysis. The concept of a contact algorithm between a master surface (mandrel) and a slave surface (soil) is used to simulate the mandrel penetrating the soil because it does not allow the elements in the soil to enter the elements in the mandrel. A Lagrangian multiplier method in the kinematics contact algorithm is used to satisfy the contact constraints and conserve momentum.

The frictional interface between soil and mandrel is modelled by the Coulomb friction contact law where the basic concept is to relate the maximum shear stress across an interface to the contact pressure between the contacting surfaces. Two contacting surfaces can carry shear stresses up to a critical shear stress $\left(\tau_{c r i t}\right)$ before sliding starts. The critical shear stress can be determined by:

$\tau_{\text {crit }}=\mu p$

where $\mu$ is the coefficient of friction and $p$ is the contact pressure. Based on Susila and Hryciw (2003), $\mu$ is assumed to be a function of the angle of effective internal friction $(\varphi)$; i.e. $\mu=\tan (0.5 \varphi)$. Therefore for a $\varphi=27^{\circ}, \mu=0.24$ (Table 1). Further discussions may be found in Abu-Farsakh et al. (2003) and Yu et al. (2000). Further detailed information of the frictional contact algorithm can be found in the ABAQUS Theory Manual (Hibbitt, Karlsson, and Sorensen, 2006).

As discussed by Cheng et al. (2005), simulating the penetration of a mandrel with a flat end always leads to divergence and problems of mesh distortion. In this study a circular mandrel with a $60^{\circ}$ conical tip is used. A confining pressure of $20 \mathrm{kPa}$ is applied along the top and centreline of the unit cell. The coefficient of lateral stress is assumed to be 0.5 .

\section{RESULTS AND DISCUSSIONS}

Figure 5 presents the deformed mesh around the mandrel. The soil close to the mandrel (distance of mandrel radius) is significantly compressed due to the shearing as the soil elements are very thin and nodes move in the vertical and horizontal directions. At the soil surface, an upward movement can be observed. The contours of total displacement are shown in Figure 6. The maximum displacement can be found near the point of the mandrel.

The contours of excess pore pressure generated while the mandrel was installed are shown in Figure 7. Maximum excess pore pressure developed much closer to the point but the significant change in mean normal effective stress below it is responsible for the excess pore water pressure. The shear strain 


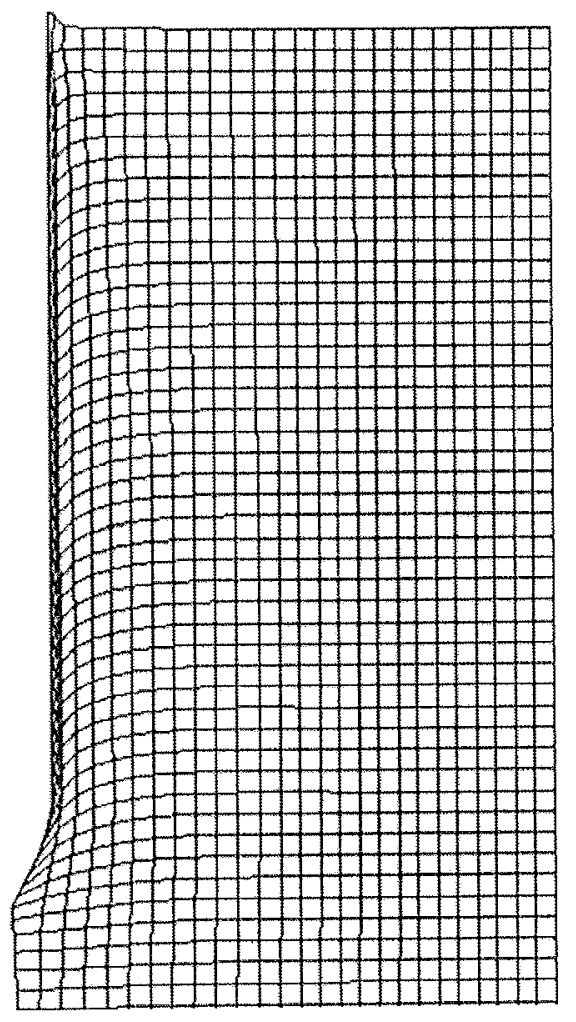

Figure 5. Deformed mesh during mandrel penetration

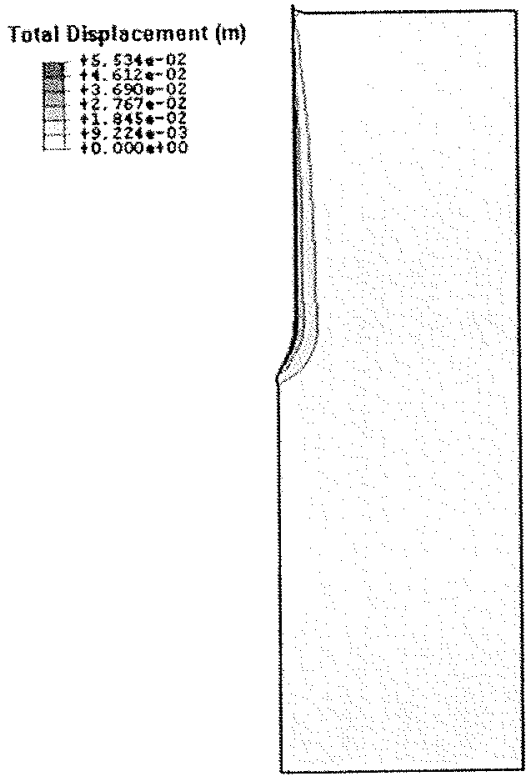

Figure 6. Total displacement contour during mandrel penetration.

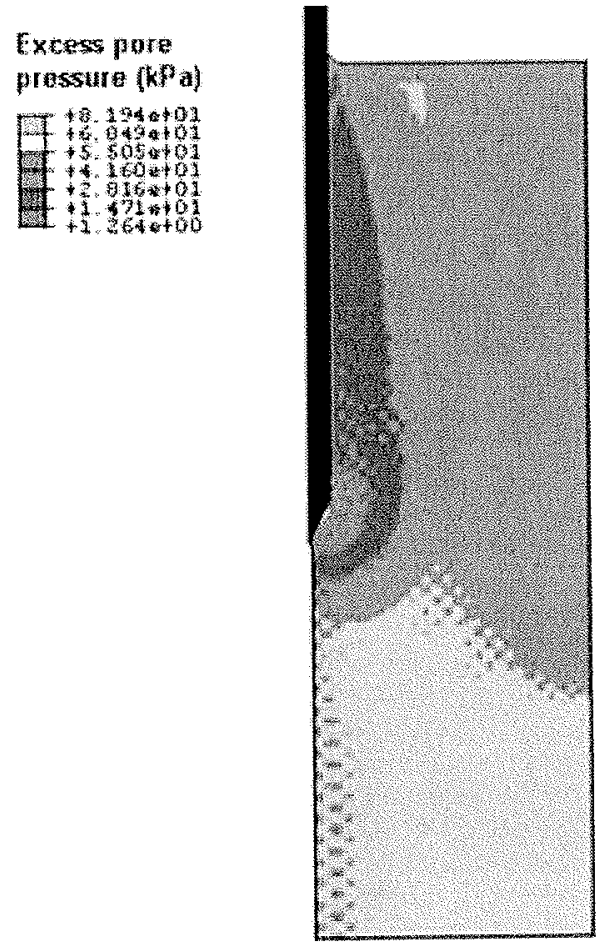

Figure 7. Excess pore pressure contour during mandrel penetration.

along the shaft of the mandrel induces excess pore pressure. A positive shear strain bulb is developed below the point but a negative shear strain is generated beside the shaft (Figure 8)

The evolution of plastic strain plotted at different stages is shown in Figure 9. The plastic zone develops beneath the point of the mandrel and around the shaft. It can be seen that the size of the plastic region is approximately 3 times the equivalent diameter of the mandrel.

Variations in pore pressure at various locations during installation and removal of the mandrel, obtained from laboratory measurements and finite element predictions, are presented in Figure 10. As observed in the laboratory, excess pore pressures increase in magnitude to a maximum value before the point of the mandrel passes below the depth where the transducers are located and then decrease gradually as the mandrel is driven deeper. Subsequently, they drop rapidly and then converge to a small residual value after the mandrel is withdrawn. However the predicted excess pore pressures still remain constant after the passage of the mandrel point and drop significantly only after it is withdrawn. 


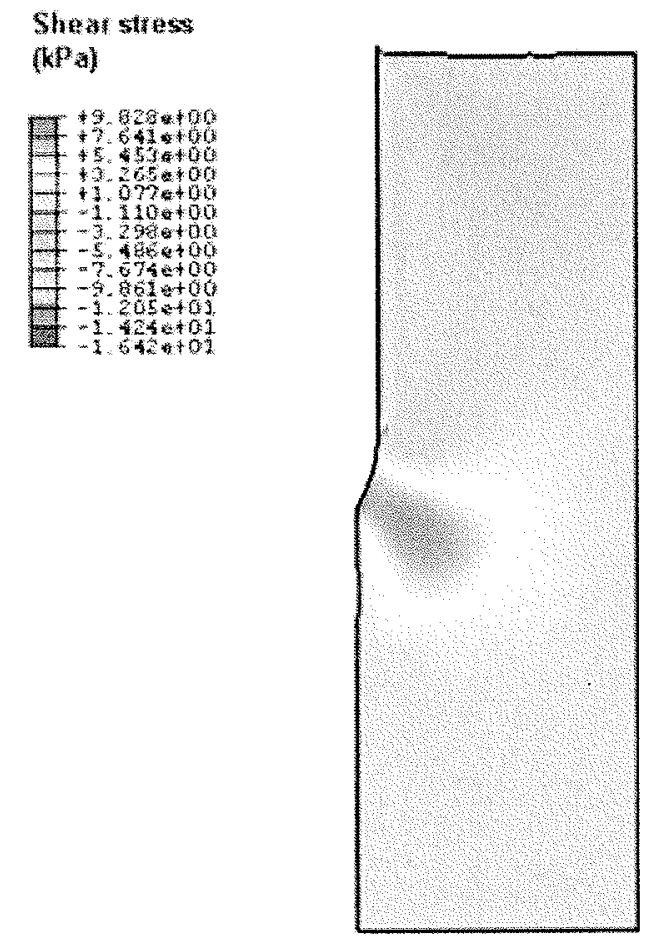

Figure 8. Shear stress contour during mandrel penetration
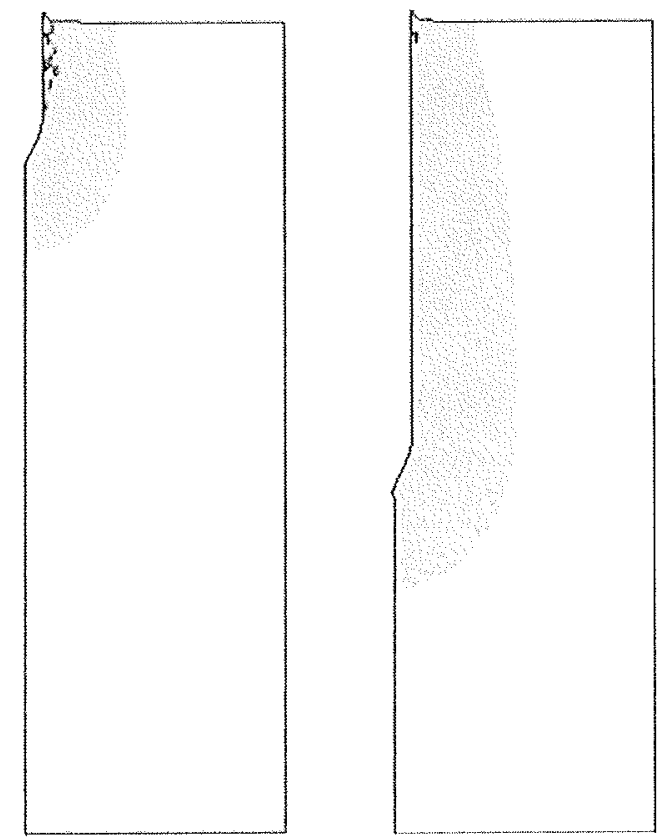

Figure 9. Development of plastic strain region during mandrel penetration.

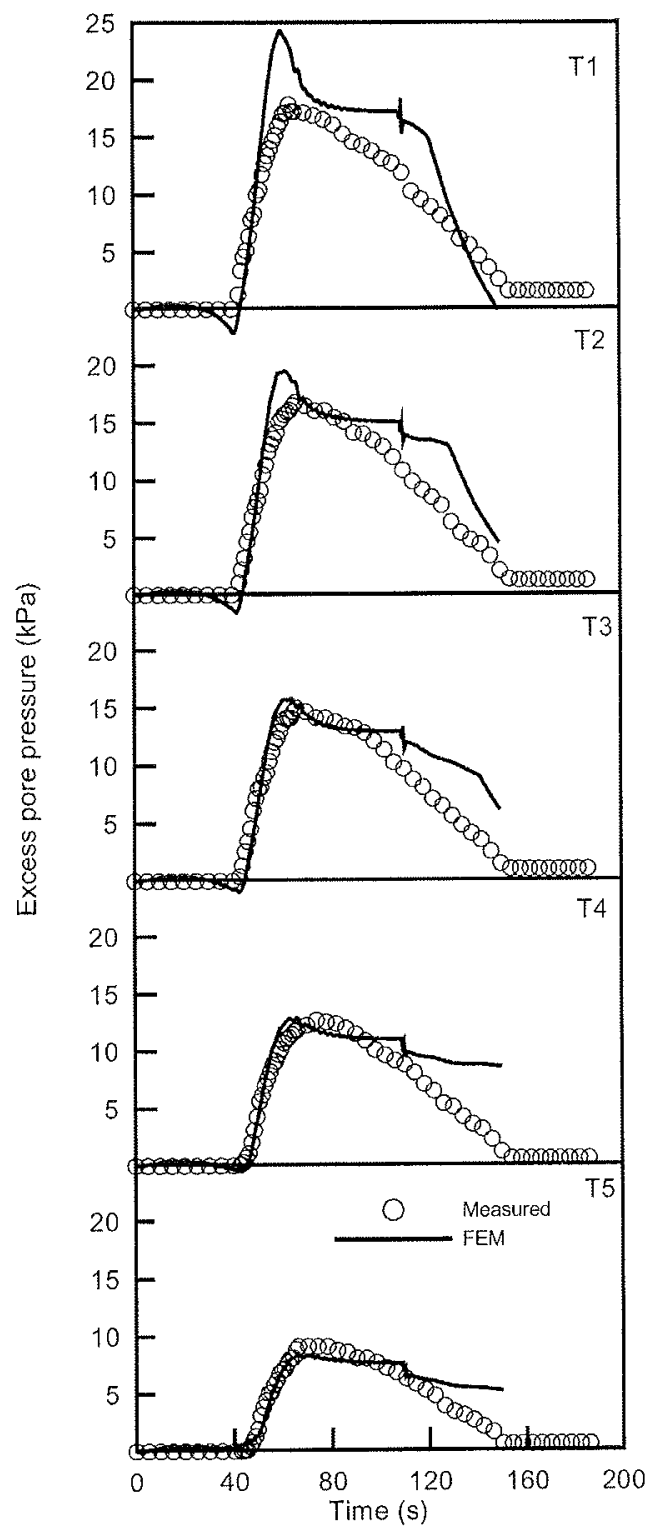

Figure 10. Predicted and measured excess pore pressure during vertical drain installation.

As discussed by Sathananthan and Indraratna (2006), the extent of the smear zone can be observed by plotting the normalised maximum excess pore pressure with the mean effective stress $\left(u / p_{0}\right)$, as shown in Figure 11. The extent of the smear zone can be extracted from $u / p_{0}>1$. It can be seen in Fig. 9 that it is approximately 2.5 times the diameter of the mandrel and is smaller than the plastic region. 


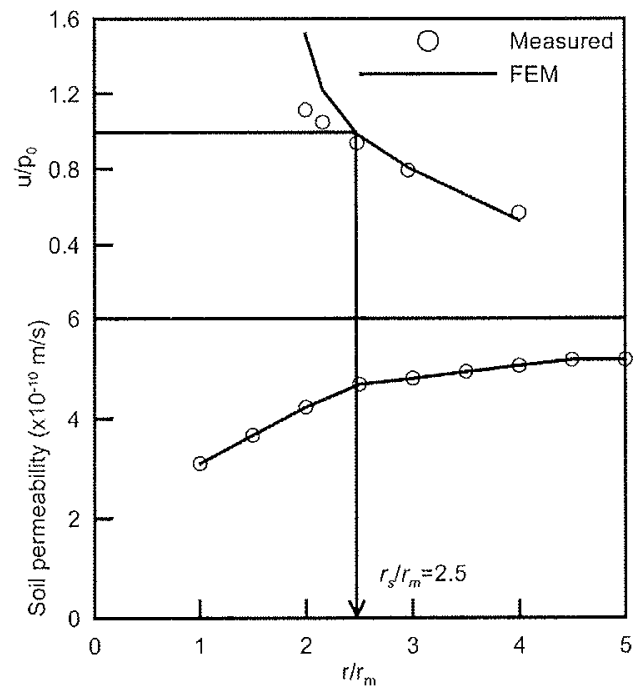

Figure 11. Extent of the smear zone based on permeability measurement and finite element prediction.

\section{CONCLUSIONS}

The installation of a mandrel driven prefabricated vertical drain was simulated under large strain condition using ABAQUS with a frictional contact interface. The soil parameters used in this numerical simulation were based on a modified Cam-clay model. It was possible to model this process but some modifications such as the size of the element, time step, and the shape of mandrel point must be carefully adapted to avoid problems with divergence. The stress and strains incurred during installation were presented. The excess pore pressures computed with the laboratory results and could be used to predict the extent of the smear zone.

\section{ACKNOWLEDGEMENT}

The authors gratefully appreciate the assistance of Professor Daichao Sheng at the University of Newcastle in the preliminary finite element simulation.

\section{REFERENCES}

Abu-Farsakh M. Tumay M and Voyiadjis G. 2003. Numerical Parametric Study of Piezocone Penetration Test in Clays, Intemational Jounal of Geomechanics, 3(2): 170-181.

Barron, R.A. 1948. Consolidation of fine-grained soils by drain wells. Transactions ASCE, 113, 718--754
Burns, S.E. and Mayne, P.W. 1998. Monotonic and Dilatory Pore Pressure Decay during Piezocone Tests in Clay, Canadian Geotechnical Journal, 35(6), 1063-1073.

Hansbo, S. 1981. Consolidation of fine-grained soils by prefabricated drains and lime column installation. Proceedings of 10th International Conference on Soil Mechanics and Foundation Engineering, Balkema (Rotterdam) 3: $677-682$.

Hibbitt, Karlsson, and Sorensen 2006. ABAQUS/Standard User's Mamual, Published by HKS Inc.

Indraratna B and Redana I.W. 1998. Laboratory determination of smear zone due to vertical drain installation. J. Geotech \& Geoen. Engng. ASCE, 124(2), 180-184.

Indraratna, B., and Redana, I.W. 2000. Numerical modeling of vertical drains with smear and well resistance installed in soft clay. Canadian Geotechnical Journal, 37: $133 \cdots 145$.

Kim, T., Kim, N., Tumay, M., Lee, W. 2007. Spatial Distribution of Excess Pore-Water Pressure due to Piezocone Penetration in Overconsolidated Clay. Journal of Geotechnical and Geoenvirommental Engineering, 133(6), 674-683,

Sathananthan, I and Indraratna, B, 2006. Laboratory Evaluation of Smear Zone and Correlation between Permeability and Moisture Content. Journal of Geotechnical and Geoenviromental Engineering, ASCE, 132(7), $942-945$.

Sharma, J.S. and Xiao, D. 2000. Characterization of a smear zone around vertical drains by large-scale laboratory tests. Canl. Geotech. J. 37(6): 1265-1271

Sheng D, Eigenbrod K.D, and Wriggers P, 2005. Finite element analysis of pile installation using large-slip frictional contact, Computers and Geotechnics, 32(1): 17-26.

Small, J.C., Booker J.R. and Davis E.H. 1976. Glasto-Platic consolidation of soil, International Joumal of Solids and Strucrures, Vol. 12, 431-448.

Susila E. and Hryciw D. 2003. Large displacement FEM modelling of the cone penetration test (CPT) in normally consolidated sand. International Joumal for Numerical and Analytical Methods in Geomechanics, 27: 585-602.

Walker, R. and Indraratna, B. 2006. Vertical drain consolidation with parabolic distribution of permeability in smear zone. $J$ of Geotechnical \& Geoenvironmental Engineering, $A S C E, 132(7), 937-941$

Walker, J. and Yu, H.S. 2006. Adaptive finite element analysis of cone penetration in. clay. Acta Geotechnica, Vol. 1, $43-57$.

Yu H.S., Hermann L.R. and Boulanger R.W. 2000. Analysis of steady cone penctration in clay, Jomnal of Geolechnical and Geoenvirommental Engineering, 126(7), 594-605. 